\title{
Korelasi antara: Kesadaran Sejarah, Religious Values dan Pemahaman Multi-Etnis terhadap Sikap Toleransi siswa SMA N Banda Aceh
}

\author{
Abdul Azis', Nurasiah' ${ }^{2}$, Widia Munira ${ }^{3}$ \\ 1,3Magister Universitas Sebelas Maret \\ ${ }^{2}$ Dosen Universitas Syiah Kuala \\ E-mail: abdazys5@gmail.com ${ }^{1}$, nurasiah.sjh@gmail.com²,munirawidia@yahoo.com ${ }^{3}$
}

\begin{abstract}
Abstrak
Penelitian ini menggunakan metode deskriptif Correlation Ex Post Facto (CEPF). Penelitian korelasi Ex Post Fakto merupakan jenis penelitian yang berfokus pada analisis hubungan antar variabel, yang diuji melalui statistik korelasional dan analisis regresi. Partisipan dalam penelitian ini berjumlah 177 siswa dari SMA Negeri Banda Aceh. Masalah utama dalam penelitian ini yaitu rendahnya prilaku sosial, sikap individualistik, hingga krisis harmonisasi dalam diri individualistik siswa. Tahapan penelitian ini meliputi uji analisis korelasi parsial, regresi sederhana dan regresi ganda. Hasil penelitian ini menunjukan bahwa: (1) terdapat hubungan positif yang signifikan antara kesadaran sejarah dengan sikap Toleransi siswa SMA N Banda Aceh; (2) terdapat hubungan positif yang signifikan antara religious values dengan sikap toleransi siswa SMA N Banda Aceh; (3) terdapat hubungan positif yang signifikan antara pemahaman multi-etnis dengan sikap toleransi siswa SMA N Banda Aceh; dan (4) terdapat hubungan secara bersama antara kesadaran sejarah, religious values dan pemahaman multietnis dengan sikap toleransi siswa. Berdasarkan hasil penelitian penulis menyatakan bahwa, peningkatan sikap toleransi disebabkan oleh tingginya sumbangan kesadaran sejarah, religious values dan pemahaman multi-etnis siswa melalui sosialisasi dalam proses pembelajaran sejarah.
\end{abstract}

Kata kunci: Kesadaran Sejarah, Religious Values, Pemahaman Multi-Etnis, Sikap Toleransi Siswa.

\section{PENDAHULUAN}

Pada setiap masa, toleransi selalu melekat dalam komunitas masyarakat. Toleransi adalah elemen penting yang terdapat dalam self (diri pribadi), Respect conception (konsepsi rasa hormat), dan conexistence conception (konsep hidup bersama). Dengan demikian, toleransi mendasari sifat yang unik yaitu berprilaku terpuji, bijaksana, memahami, menghargai, dan menahan, serta mengacu pada penerimaan kondisi terhadap suatu obyek yang berbeda dengan kondisi yang dirasakan, atau tidak terinterfensi oleh kepercayaan lain, dan untuk kemaslahatan hidup bersama (Forst, 2012). Dalam kaitanya dengan peranan pertama yaitu respect, setiap individu harus bertindak dengan mengproduksi rasa menghargai sesama masyarakat, dengan mengembangkan konsep harmonisasi sehingga self akan terbentuk melalui konsepsi tersebut. Sementara itu, pada konsepsi yang kedua setiap individu bertindak dalam kerangka Conexistence yaitu kehidupan yang mendasari kebersamaan, keberagaman dan kekompakan untuk mencapai solidaritas antar etnisitas masyarakat (Parsons, 2013).

Dalam dua konsepsi tersebut, toleransi mempengaruhi kapasitas individu agar terbentuk sikap yang terpuji dan damai. Dengan demikian, sikap toleransi mempunyai unsur-unsur yang harus di tekankan dalam mengekspresikannya terhadap orang lain. Unsur-unsur tersebut adalah; (1) freedom (memberikan kebebasan atau kemerdekaan); (2) human right (mengakui Hak Setiap Orang); (3) human and religius menghormati keyakinan orang lain (Calder, dkk, 2014). Berbakal sikap toleransi yang dimilikinya, seseorang dapat mendorong dan memiliki sikap solidaritas.

Rendahnya sikap toleransi dalam diri seseorang menyebabkan krisis penerimaan terhadap divergensi dalam masyarakat. Krisis toleransi bukan berarti ketiadaan sikap toleransi dalam masarakat, tetapi lebih kepada ketiadaan sifat-sifat sikap toleransi yang idealnya harus dimiliki oleh setiap individu. Krisis toleransi disebabkan oleh dua dimensi, yaitu: personal dan group. Dimensi personal merujuk pada elemen dan hastrat yang terdapat dalam self (diri pribadi) individu. Hastrat dalam suatu karakter 
masyarakat yang khas dan karakter masyarakat yang khas ini adalah inkubotor yang menyamai psikologis dan mentalitas seorang individu, akibat dari krisis sikap toleransi ini adalah individu tidak dapat berperan maksimal (mediocrity) dalam masyarakat (Burs, 2010).

Tindakan intoleransi tidak hanya mengacu pada dorongan personal tetapi juga mencakup aspek struktural yang berkaitan dengan struktur, sistem ataupun budaya sosial dalam politik masyarakat (Parson, 2013). Dari sisi personal, intoleransi dapat disebabkan oleh hastrat diri yang menggangap diri paling benar, tidak mengakui serta tidak menerima etnisitas dan kejahatan sistematik serta kekosongan, selain itu intoleransi dipengaruhi oleh lingkungan dan struktur tempat manusia bersosial (Calder, dkk, 2014).

Berdasarkan hasil wawancara, ditemukan beberapa fakta yang menarik di SMA Negeri Banda Aceh. Salah satunya yaitu rendahnya sikap toleransi, kurangnya pemahaman solidaritas, buruknya prilaku sosial, pergaulan bebas serta Pada sisi lain, terjadinya permasalah sosial etnis, baik dalam ranah agama, kebudayaan dan perbedaan pendapat. Hal ini memicu konflik di berbagai daerah, tawuran antar pelajar atau konflik yang berbau SARA. Oleh karena itu, sehingga Perlunya menanggulangi permasalahan krisis intoleransi dalam diri siswa. Peranan sikap toleransi dalam progres peradaban serta permasalahan krisis intoleran yang telah dijelaskan menunjukkan perlunya urgensi pengembangan dan peningkatan toleransi dalam diri self siswa.

Dalam sudut pandang peneliti, pendidikan memiliki posisi fundamental dalam mengembangkan sikap toleransi, dalam konteks pendidikan terjadi proses sosialisasi dan daya cipta dalam aktivitas pembelajaran. Sosialisasi mengarah aktivitas masyarakat untuk mempelajari norma, pandangan dan kearifan yang terdapat dalam lingkungannya. Pada indikator proses sosialisasi, norma berperan penting dalam mengendalikan dan menentukan prilaku sosialisasi bertujuan agar perilaku dan tindakan yang dilakukan oleh individu sesuai dengan kerangka norma yang telah mengakar dalam masyarakat (Parson, 2013). Proses sosialisasi, selain menghasilkan individu yang bertindak sesuai struktur norma, juga memberikan peluang bagi daya cipta individu (Durkheim, 2013). Dengan demikian, melalui proses sosialisasi diatas, maka sikap toleransi akan terbentuk dalam self seseorang.

\section{METODE}

Desein Correlation Ex Post Facto (CEPF), oleh Gall, Gall \& Borg (2013), diadopsi untuk mencari keterkaitan antara hubungan kesadaran sejarah, religious values, dan multi-etnis terhadap sikap toleransi. Pada tahap analisis deskripsi data, penulis mendeskripsikan masalah yang berkaitan dengan toleransi siswa di SMA Banda Aceh. Sedangkan pada tahapan desain korelasi menghasilkan protetype model analisis. Tahap korelasi terdiri dari langkah: uji prasyarat analisi dan uji hipotesis.. Tahapan terakhir yaitu sumbangan prediktor antara variabel bebas terhadap variabel terikat melalui.

Responden dalam penelitian ini berjumlah 177 siswa dari SMA Negeri di Banda Aceh. Data dikumpulkan dengan menggunakan angket yang berjumlah 120 pertanyaan dari 3 variabel yaitu kesadaran sejarah $\left(\mathrm{X}_{1}\right)$, religious values $\left(\mathrm{X}_{2}\right)$, pemahaman multi-etnis $\left(\mathrm{X}_{3}\right)$, dan sikap toleransi $(\mathrm{Y})$. Selengkapnya disajikan pada tabel 1.

Tabel 1. Data Proporsi Sampel SMA Negeri di Banda Aceh

\begin{tabular}{lllll}
\hline No & Nama SMA & Populasi & Perhitungan & Sampel \\
\hline 1. & SMA Negeri 1 Banda Aceh & 80 & $(80: 318) \times 177$ & 45 \\
2. & SMA Negeri 2 Banda Aceh & 78 & $(78: 318) \times 177$ & 43 \\
3. & SMA Negeri 3 Banda Aceh & 83 & $(83: 318) \times 177$ & 47 \\
4. & SMA Negeri 4 Banda Aceh & 77 & $(77: 318) \times 177$ & 42 \\
\hline & Jumlah & 318 & & 177 \\
\hline
\end{tabular}

Analisis data menggunakan Program SPSS 22 


\section{HASIL DAN PEMBAHASAN}

Temuan tahap Prasyarat analisis data antara lain adalah:

\section{Uji Normalitas data}

Pada tahapan analisis data yang pertama, yaitu; (1) uji normalitas data variabel kesadaran sejarah menggunakan uji Kolmogorof-Smirnov. Hasil uji analisis dari 177 responden yang di ambil dan didapatkan $p$-value $=0,200$, sedangkan $\alpha=0,05$, maka $p$-value $(0,200)>0,05$; (2) uji normalitas data variabel religious valuesmenggunakan uji Kolmogorof-Smirnov. Hasil uji dari 177 responden yang di ambil dan didapatkan $p$-value $=0,200$, sedangkan $\alpha=0,05$, maka $p$-value $(0,200)>0,05$; (3) uji normalitas data variabel multi-etnis menggunakan uji Kolmogorof-Smirnov. Hasil uji dari 177 responden yang di ambil dan didapatkan $p$-value $=0,200$, sedangkan $\alpha=0,05$, maka $p$-value $(0,200)>0,05$,; dan (4) uji normalitas data variabel sikap toleransi menggunakan uji Kolmogorof-Smirnov. Hasil uji dari 177 responden yang di ambil didapatkan $p$-value $=0,200$, sedangkan $\alpha=0,05$, maka $p$-value $(0,200)>$ 0,05 . Hasil analisis uji normalitas, yang diperoleh 177 responden dari 120 item pertanyaan disajikan pada tabel 2.

Tabel 2. Analisis Uji Normalitas

\begin{tabular}{ccccccc}
\hline \multirow{2}{*}{ Varibel } & \multicolumn{5}{c}{ Kolmogorov-Smirnov } \\
\cline { 2 - 7 } & Statistik & df & p-value & $\alpha$ & Kondisi & Kesimpulan \\
\hline Variabel X $X_{1}$ & 0,046 & 177 & 0,200 & 0,05 & $>\alpha$ & Distribusi Normal \\
Variabel $X_{2}$ & 0,046 & 177 & 0,200 & 0,05 & $>a$ & Distribusi Normal \\
Variabel $X_{3}$ & 0,057 & 177 & 0,200 & 0,05 & $>\alpha$ & Distribusi Normal \\
Variabel Y & 0,051 & 177 & 0,200 & 0,05 & $>\alpha$ & Distribusi Normal
\end{tabular}

Sumber Analisis Data Primer Hasil Uji Normalitas SPSS Versi 22

\section{Uji Linearitas}

Pada tahapan analisis data yang kedua, yaitu; (1) uji linearitas hubungan kesadaran sejarah terhadap sikap Toleransi. Hasil perhitungan menggunakan program SPSS versi 22, menunjukkan bahwa nilai signifikan linearity sebesar 0,000 . Oleh karena itu signifikan kurang dari 0,05 maka dapat disimpulakn bahwa variabel $X_{1}$ dan $Y$ linear. Hal ini sesuai dengan kaidah bahwa apabila nilai sig $<0,05$ maka hubungan yang terjadi adalah linear; (2) uji linearitas religious values terhadap sikap Toleransi. Hasil perhitungan menggunakan program SPSS versi 22, menunjukkan bahwa nilai signifikan linearity sebesar 0,000. Oleh karena itu, signifikan kurang dari 0,05 $\mathrm{X}_{2}$ dan $\mathrm{Y}$ linear; dan (3) uji linearitas multietnis dengan sikap Toleransi. Hasil perhitungan menggunakan Program SPSS versi 22, menunjukkan bahwa nilai signifikan linearity sebesar 0,000 . Oleh karena itu signifikan kurang dari 0,05 maka dapat disimpulakn bahwa variabel $\mathrm{X}_{3}$ dan $\mathrm{Y}$ linear. Hasil analisis uji linearitas, yang diperoleh 177 responden dari 120 item pertanyaan disajikan pada tabel 3.

Tabel 3. Analisis Uji linearitas

\begin{tabular}{lccccc}
\hline No. & Variabel & Fhitung & $\mathrm{P}$ & Kondisi & Kesimpulan \\
\hline 1 & Variabel $\mathrm{X}_{1}><$ Variabel $\mathrm{Y}$ & 121,115 & 0,000 & 0,05 & Linear \\
2 & Variabel $\mathrm{X}_{2}<<$ Variabel $\mathrm{Y}$ & 38,559 & 0,000 & $<0,05$ & Linear \\
3 & Variabel $\mathrm{X}_{2}><$ Variabel $\mathrm{Y}$ & 147,985 & 0,000 & $<0,05$ & Linear \\
\hline
\end{tabular}

Sumber: Analisis Data Uji Linearitas menggunakan SPSS Versi 22.

\section{Uji Multikolinearitas}

Uji multikolinearitas bertujuan untuk mengetahui hubungan yang sempurna atau pasti diantara satu variabel atau lebih variabel independen dalam model. Hasil analisis uji multikolinearitas, yang diperoleh 177 responden dari 160 item pertanyaan disajikan pada tabel 4. 
Tabel 4. Hasil Analisis Uji Multikolinearitas

\begin{tabular}{ccccc}
\hline Variabel & Tolerance & Nilai VIF & Kondisi & Kesimpulan \\
\hline Kesadaran Sejarah & 0.824 & 1.213 & $<10$ & $\begin{array}{c}\text { Tidak terjadi } \\
\text { multikolinearitas }\end{array}$ \\
Religious Values & 0.933 & 1.071 & $<10$ & $\begin{array}{c}\text { Tidak terjadi } \\
\text { multikolinearitas } \\
\text { Pidak terjadi } \\
\text { multikolinearitas }\end{array}$ \\
\hline
\end{tabular}

Sumber: Analisis Data Hasil Uji Mutikolinearitas menggunakan SPSS Versi 22

Berdasarkan tabel 4.15 menunjukkan bahwa nilai VIF (variance inflation factor) disekitar angka satu, dan mempunyai tolerance value mendekati satu (atau nilai tolerance kurang dari 10) yang berarti bahwa semua variabel bebas tidak ada atau tidak terjadi multikolinearitas.

\section{Uji Autokorelasi}

Uji autokorelasi digunakan untuk mendeteksi dimana variabel dependen tidak berkorelasi dengan dirinya sendiri, baik nilai periode sebelumnya atau nilai periode sesudahnya. Pengujian autokorelasi dilakukan dengan menggunakan uji Durbin Watson. Bila DW tepat sama dengan 2, tidak terjadi autokorelasi sempurna, jika nilai DW antara 1,3 sampai 2,5, data tidak mengalami autokorelasi. Jika niali DW lebih dari 2,4, data terjadi autokorelasi negatif. Hasil analisis uji autokorelasi, yang diperoleh 177 responden dari 160 item pertanyaan disajikan pada tabel 5 .

Tabel 5. Hasil Analisis Uji Autokorelasi

\begin{tabular}{cccccc}
\hline Model & $\mathrm{R}$ & $\mathrm{R}$ Square & $\begin{array}{c}\text { Adjusted R } \\
\text { Square }\end{array}$ & $\begin{array}{c}\text { Std. Error of } \\
\text { the Estimate }\end{array}$ & Durbin-Watson \\
\hline 1 & $0,778^{\mathrm{a}}$ & 0,606 & 0,599 & 6,791 & 2,293 \\
\hline
\end{tabular}

a. Predictors: (Constant), kesadaran sejarah $\left(\mathrm{X}_{1}\right)$, religious values $\left(\mathrm{X}_{2}\right)$, pemahaman multi-etnis $\left(\mathrm{X}_{3}\right)$

b. Dependent Variable: Sikap Toleransi Siswa $(\mathrm{Y})$

c. Hasil Analisis Uji Autokorelasi Menggunakan SPSS Versi 22

Berdasarkan tabel 5 , nilai Durbin Watson dalam model regresi pada penelitian ini sebesar 2,293 berada antara du sampai 4-du, yang berartikan tidak terjadi autokorelasi. Pada tingkat signifikansi $5 \%$ hasil pengujian menunjukkan bahwa Dw hitung $(2,293)$ berada diantara 2,20-2,250 berarti persamaan regresi yang digunakan dalam keadaan tidak terjadi autokorelasi atau data dalam penelitian ini normal tidak error/residual.

\section{Uji Heteroskedastisitas}

Berdasarkan hasil deskripsi data menunjukkan bahwa ketiga variabel memiliki nilai sig diatas 0,05 , sehingga dapat dikatakan tidak terjadi masalah heterokedastisitas atau data dinyatakan valid. Hasil analisis disajikan pada tabel 6 .

Tabel 6. Hasil Analisis Uji Heterokedastisitas

\begin{tabular}{cccc}
\hline Variabel & thitung & Sig. & Keputusan \\
\hline Kesadaran Sejarah &,-882 & 0,379 & Tidak terjadi heteroskedastisitas \\
Religous Values &,-670 & 0,504 & Tidak terjadi heteroskedastisitas \\
Pemahaman Multi-Etnis &, 316 & 0,752 & Tidak terjadi heteroskedastisitas \\
\hline
\end{tabular}

Sumber: Data Uji Heteroskedastisitas diolah menggunakan SPSS Versi 22.

\section{Uji Hipotesis}

Berdasarkan karakteristik data masing-masing variabel yang diperoleh dari uji prasyarat analisis, maka tahap selanjutnya adalah melakukan pengujian hipotesis, penafsiran pengujian hipotesis dan kesimpulan pengujian hipotesis terhadap variabel-variabel penelitian. Hasil analisis disajikan pada tabel 7: 
Tabel 7. Hasil Analisis Uji Hipotesis

\begin{tabular}{ccccc}
\hline No & Variabel & Korelasi Parsial & $\begin{array}{c}\text { Regresi Sederhana dan } \\
\text { Regresi Ganda }\end{array}$ & $\begin{array}{c}\text { Kofisien } \\
\text { Determinasi }\end{array}$ \\
\hline 1 & $\mathrm{X} 1><\mathrm{Y}$ & 0,417 & 0,430 & $17,4 \%$ \\
2 & $\mathrm{X} 2><\mathrm{Y}$ & 0,623 & 0,622 & $38,8 \%$ \\
3 & $\mathrm{X} 3><\mathrm{Y}$ & 0,597 & 0,563 & $35,6 \%$ \\
4 & $\mathrm{X} 1, \mathrm{X} 2, \mathrm{X} 3><\mathrm{Y}$ & 0,778 & $0,264.0,388.0,407$, & $60,6 \%$ \\
\hline
\end{tabular}

Sumber: Data Uji Hipotesis Menggunakan Program Statistik SPSS Versi 22

\section{Pembahasan}

Hasil analisis data menjelaskan bahwa, peningkatan nilai determinasi keempat variabel tersebut, memperkuat asumsi teoritik, yang berarti peserta didik pada dasarnya telah memiliki pemahaman dan pengetahuan awal mengenai sikap toleransi, sehingga kesadaran sejarah, religious values dan multietnis, terinternalisasi kemudian di olah dalam long term memory peserta didik dan menghasilkan suatu produksi pengetahuan baru yaitu the solidarity of identity (Dijk, 2015). Pada dasarnya, seorang individu telah memiliki pengetahuan kesejarahanya yang didapatkanya melalui akumulasi pengalaman ataupun dari sumber informasi yang lain diluar proses pembelajaran, seperti aspek cultural, sosial, dan pembacaan buku, website, flm, museum dan sumber-sumber lain. Wawasan kesejarahan ini dikategorikan sebagai basis kognitif yang mempengaruhi pemikiran, persepsi, pemahaman dan wacana dari seorang individu (Dijk, 2015). Misalnya, bagi siswa yang berasal dari Aceh, pemahaman qanun multi-etnis danSyariat Islam adalah sebuah kearifan lokal yang penting untuk dipelajari. Sementara bagi mahasiswa yang berasal dari luar Aceh, Syariat Islam akan dimaknai secara berbeda, sebagai suatu informasi terhadap budaya lain. Persepsi budaya ini mempengaruhi seorang individu untuk menerima dan menerjemahkan nilai-nilai budaya yang diserapnya dalam proses pembelajaran. Oleh karena itu, masyarakat Aceh dapat dikategorikan sebagai suatu komunitas epistemik tempat individu-individu berbagi ideologi dan pengetahuan. Komunitas epistemik ini bersifat mendua, disatu sisi hal ini dapat menjadi pembatas dalam memahami suatu obyek budaya, semetara itu, disisi lain, komunitas epistemik ini dapat menjembatani cross cultural fertilization jika disertai dengan kesadaran untuk menerima keberadaan budaya lain dalam masyarakat.

Keberadaan kesadaran sejarah, religious values dan pemahaman multi-etnis berkontribusi terhadap produksi sikap toleransi siswa. Artinya, keberadaan ketiga variabel tersebut mempengaruhi aspek afektif siswa dengan memberikan suatu pemahaman kognitif mengenai sikap-sikap toleransi kepada siswa. Pemahaman kognitif tersebut secara teoritik akan mempengaruhi aspek efektif siswa, dampak pemahaman ke empat variabel tersebut, terhadap kognitif mengarah pada tujuan pendidikan post-moderen (Usher \& Edwerds, 20013). Dengan demikian, kelemahaman dari pendidikan moderen adalah menghasilkan manusia-manusia yang individualis, arogan dan konsumerisme, maka dari itu mereka menyarankan untuk menggunakan aspek nilai-nilai kearifan lokal untuk menambal kelemahan pendidikan moderen (Azis \& Hermanu, dkk 2018). Pola menggunakan kearifan lokal ini sudah menjadi pola kecenderungan bagi pendidikan sosial di dunia, khususnya di negara-negara yang memiliki basis kekayaan kearifan lokal (Forst, 2014). Hubungan pemahaman 4 variabel tersebut dan berhasil menyediakan ruang bagi nilai kearifan lokal untuk meningkatkan aspek afektif siswa yaitu sikap toleransi. Sikap toleransi siswa menjadi bagian penting dalam mengarah para aktor untuk memperkuat aspek solidaritas dalam dunia modern yang individualis.

Hubungan antara variabel kesadaran sejarah terhadap sikap toleransi menghasilkan hubungan yang positif dan signifikan, dibuktikan dengan sumbangan variansi sebesar $35,6 \%$, hal ini dapat dijelaskan bahwa peningkatan kesadaran sejarah akan mempengaruhi sikap toleransi. Sementara itu, sejarah berfungsi untuk memperjelas masa lalu serta menjelaskan berbagai peristiwa dan maknanya secara jelas dan menempatkan manusia pada arah kehidupan multikultural. Faktor multikultural sangat penting sebagai bentuk kekuatan dan kepaduan masyarakat yang menjadi unsur utama dalam keberhasilan dan efektivitas masyarakat (Rowse, 2014). Dengan demikian, apabila seseorang siswa memiliki kesadaran sejarah, maka dapat dipastikan akan memiliki sikap yang positif terhadap tanah air 
serta keberagamaan suatu etnis, suku, dan bangsa, yang digambarkan dengan perasaan cinta, kesadaran terhadap identitas dan solidaritas, akan mempengaruhi terbentuknya sikap toleransi (Abdullah, 2018).

Berdasarkan analisis data determinasi , keterkaitan antara variabel religous values terhadap sikap toleransi yaitu 38,8\%, hasil ini menunjukkan bahwa peningkatan pemahaman religous values akan mempengaruhi peningkatan sikap toleransi. Dengan demikian, asumsi penulis bahwa, identitas masyarakat Indonesia yang serba majemuk dalam berbagai dimensi kulturalnya sehingga mampu menyadarkan warga negara akan pentingnya arti hidup bersama atas dasar keberagaman, kebhinnekaan, persamaan hak dan kewajiban berdasarkan hukum yang berlaku. Hal ini terbentuk sebagai produk sejarah dalam sejarah kebudayaan masyarakat Indonesia yaitu persamaan senasib, bersatu dan berjuang bersama untuk mendirikan dan membangun bangsa ( Azis \& Hermanun dkk, 2018). dengan demikian, multi etnis, suku bangsa, dan kebuadayaan akan mempengaruhi keberagaman hidup dan saling menghargai sebagai wadah menuju power of prospety (Smith, \& Cohran, 2008). Hal ini di perkuat dengan asumsi ahli bahwa, Indonesia merupakan terdapat banyak suku bangsa, bahasa, agama, dan sebagainya yang masing-masing mempunyai sejarahnya sendiri sehingga perlunya nilai religius yang bertopang pada persamaan (Peterson \& Davies, 2011). Berdasarkan deskripsi tersebut, nilai religius sangat berpengaruh dalam pembentukan sikap toleransi siswa, dikarenakan siswa dapat memahami pentingnya kemajemukkan suatu bangsa sebagai wadah memperkuat identitas nasional. Dengan demikian, kebangsaan yang memiliki latar belakang luas serta kejelian dalam melihat dan memahami akar-akar komunalisme, sekterianisme, atau primordialisme (Tilaar, 2007).

Pemahaman multi-etnis atau keberagaman memperlihatkan koefisiensi determinas 35,6\%, hasil tersebut diperoleh dari responden siswa SMA Negeri Banda Aceh. Dengan demikian, hal ini diyakini semakin dalam atau semakin banyak seseorang mengenal dan memahami etnisitas maka akan mempengaruhi tingginya peningkatan sikap toleransi. Temuan ini memperkuat asumsi bahwa Indonesia merupakan negara yang terdiri dari multietnis, suku bangsa, kebudayaan dan agama, maka perlunya pemahaman kesadaran sejarah kebhinnekaan dan nilai multi religous, hal ini agar terciptanya suasana yang aman, kondutif dan jauh dari konflik sehingga akan mempengaruhi pembentukan sikap saling menghargai dan menghormati serta toleransi, maka hal tersebut akan mempengaruhi aktivitasaktivitas masyarakat (Peterson\& Davies, 2011). Sementara itu, Azis dkk (2018) menjelaskan pendapat bahwa, keberagaman suku bangsa dan etnis terdapat hampir diseluruh wilayah Indonesia, salah satunya terdapat di provinsi Aceh, bahwa Aceh merupakan salah satu daerah yang menerapkan konsep toleransi dalam adat istiadat, peraturan daerah (Qanun, Syariat Islam) serta dalam dunia pendidikan. Maka salah satu konsep kebinnekaan harus diajarkan dalam pembelajaran kewarganegaraan dan sejarah, agar kesadaran terhadap pentinya persatuan akan terbentuk melalui pembelajaran disekolah maka akan melahirkan konsep toleransi

\section{PENUTUP}

\section{Simpulan}

Berdasarkan perhitungan analisis data dan pembahasan hasil penelitian, tentang hubungan kesadaran sejarah, religious values dan pemahaman multi-etnis terhadap sikap toleransi siswa, dapat disimpulkan bahwa terdapat hubungan yang positif dengan perhitungan korelasi sebesar 0,778. Sedangkan hasil hipotesis menunjukkan bahwa nilai $F_{\text {hit }}=88,597>F_{\text {tab }}=2,660$, dengan taraf signifikan $0,000<0,05$, dengan sumbangan $60,6 \%$. Oleh karena itu, $(\mathrm{Ho})$ diterima dan $(\mathrm{Ha})$ ditolak.

\section{Saran}

Berdasarkan hasil penelitian ini, saran diberikan kepada berbagai pihak, antara lain sebagai berikut; (1) bagi sekolah di harapkan agar dapat berperan dalam pengambilan kebijakan guna mendukung pembelajaran berbasis kearifan lokal meliputi, kesadaran sejarah, religious values dan 
pemahaman multi-etnis untuk meningkatkan sikap toleransi siswa SMA di Banda Aceh; (2) hasil penelitian ini dapat dijadikan acuan kepada guru agar berkontribusi dalam meningkatkan sikap toleransi siswa, dengan penanaman nilai-nila keberagaman kepada siswa SMA di Banda Aceh; (3) Siswa diharapkan agar selalu belajar dalam meningkatkan sikap toleransi di sekolah ataupun dilingkungan masyarakat. Salah satunya dengan cara memahami religious values dan multi-etnis dalam proses pembelajaran sejarah di sekolah.

\section{UCAPAN TERIMAKASIH}

Ucapan terimakasih kepada Universitas Sebelas Maret Surakarta, dosen Universitas Syiah Kuala Banda Aceh, dan guru SMA Negeri di Banda Aceh, yang telah berkontribusi dalam menyelesaikan penelitian dan penulisan ini.

\section{DAFTAR PUSTAKA}

Abdullah, I.(2018). Konflik Etno-Religius di Asia Tenggara. Yogyakarta: LkiS Press

Azis, A. Joebagio, H, \& Sudiyanto. (2018). Correlation Between: Understanding of NATIONALISM and Historical Consciousness toward Students' Democratic Attitude in Banda Aceh Senior High School, International Journal of Multicultural and Multireligious Understanding, 5(3), 60-71.

Burs, J. M. (2010). Leadership. New York: Herperperennial Press.

Calder, G., Bessone, M., \& Zuolo, F. (2014). How Groups Matter: Challenges of Toleration in Pluralistic Societies. London: Rauledge Taylor \& Prancis Grop.

Dijk, T. A. (2015). Critical Discourse Studies; A Sociocognitive Approach. In R. Wodak, \& M. Meyer, Journal Methods of Critical Discourse Analysis, 2(4), 62-85.

Durkheim, E. (2013). The Division of Labour in Society. (Steven Lukes). United Kingdom: Palgrave Macmillan (Original Work Published 1961).

Forst, R .(2014). The Power of Tolerance, with Wendy Brown, New York: Columbia University Press.

Gall, M. D., Gall, Joyce. P \& Borg, Walter. R. (2003). Educational Research. United States: University of Oregon.

Parsons, T. (2013). The Sosial System. London: Rauledge Taylor \& Prancis Grop.

Peterson, A., \& Davies,. I. (2011). Debetes in History Teaching. London: Taylor \& Prancis Group.

Rowse. (2014). Introduction, Antropology, Collecting and Colonial Govermentalis.London: Taylor \& Prancis Grop.

Smith \& Cochran. (2008). Walking The Road: Race, diversitu, and social Justice in teacher education. New York: Teacher College Press.

Tilaar, H. A. R. (2007). Mengindonesia Etnisitas dan Identitas. Jakarta: Rineka Cipta.

Usher, R., \& Edwerds, R. (2013). Postmodernsm and Education: Different voices, different worlds, London: Routledge taylor \& Prancis e-Library. 